\title{
Mechanisms regulating melanogenesis*
}

\author{
Mecanismos reguladores da melanogênese
}

Inês Ferreira dos Santos Videira ${ }^{1}$

Sofia Magina ${ }^{3}$

\author{
Daniel Filipe Lima Moura²
}

\begin{abstract}
Skin pigmentation is an important human phenotypic trait whose regulation, in spite of recent advances, has not yet been fully understood. The pigment melanin is produced in melanosomes by melanocytes in a complex process called melanogenesis. The melanocyte interacts with endocrine, immune, inflammatory and central nervous systems, and its activity is also regulated by extrinsic factors such as ultraviolet radiation and drugs. We have carried out a review of the current understanding of intrinsic and extrinsic factors regulating skin pigmentation, the melanogenesis stages and related gene defects. We focused on melanocyte-keratinocyte interaction, activation of melanocortin type 1 receptor (MC1-R) by peptides (melanocyte-stimulating hormone and adrenocorticotropic hormone) resulting from proopiomelanocortin (POMC) cleavage, and mechanisms of ultraviolet-induced skin pigmentation. The identification and comprehension of the melanogenesis mechanism facilitate the understanding of the pathogenesis of pigmentation disorders and the development of potential therapeutic options.
\end{abstract}

Keywords: Keratinocytes; Melanocytes; Pigmentation disorders; Skin pigmentation; Solar radiation

Resumo: A pigmentação da pele é um importante traço fenotípico do ser humano mas apesar dos recentes avanços a sua regulação não está ainda totalmente esclarecida. O pigmento melanina é produzido nos melanossomas pelos melanócitos, num processo complexo designado por melanogénese. $\mathrm{O}$ melanócito interatua com os sistemas endócrino, imunitário, inflamatório e nervoso central e a sua atividade é também regulada por fatores extrínsecos como a radiação ultravioleta e fármacos. Fizemos uma revisão do conhecimento atual sobre os fatores intrínsecos e extrínsecos reguladores da pigmentação cutânea, etapas da melanogénese e defeitos genéticos relacionados. Fizemos enfoque na interação melanócito-keratinócito, na ativação do receptor da melanocortina tipo 1 (MC1-R) pelos péptidos (hormona estimuladora do melanócito e hormona adrenocorticotrófica) resultantes da clivagem da proopiomelanocortina (POMC) e mecanismos da pigmentação induzida pela radiação ultravioleta. A identificação e compreensão dos mecanismos reguladores da pigmentação cutânea facilitam o conhecimento dos mecanismos patogénicos dos distúrbios da pigmentação e o desenvolvimento de potenciais opções terapêuticas.

Palavras-chave: Melanócitos; Pigmentação da pele; Queratinócitos; Radiação solar;

Transtornos da pigmentação

Received on 26.01.2012.

Approved by the Advisory Board and accepted for publication on 15.05.2012.

* Work conducted at the Institute of Pharmacology and Therapeutics, School of Medicine, University of Porto (IFT -FMUP) - Porto, Portugal.

Conflict of interest: None

Financial Support: None

PhD - Department of Pharmacology and Therapeutics, School of Medicine, University of Porto (Universidade do Porto) - Porto, Portugal.

PhD Professor - Department of Pharmacology and Therapeutics, School of Medicine, University of Porto (Universidade do Porto) - Porto, Portugal.

PhD Professor - Department of Pharmacology and Therapeutics, School of Medicine, University of Porto and Service of Dermatology and Venereology, Sao Joao

Hospital (Hospital de Sao Joao) - Porto, Portugal.

(C)2013 by Anais Brasileiros de Dermatologia 


\section{INTRODUCTION}

The skin has epidermal units that are responsible for melanin production and distribution, a process called melanogenesis. These units are composed of a melanocyte surrounded by keratinocytes and regulated by a closed paracrine system. Melanin is the primary determinant of skin, hair, and eye color. Besides defining an important human phenotypic trait, it has a critical role in photoprotection due to its ability to absorb ultraviolet radiation (UVR). ${ }^{1-3}$ The Fitzpatrick system is the most commonly used system to distinguish different skin pigmentation phenotypes. It characterizes six phototypes (I-VI) by grading erythema and acquired pigmentation after exposure to UVR. ${ }^{1,4}$ Constitutive pigmentation reflects the genetically determined level of melanin and can be changed by several regulatory factors. ${ }^{3,5}$ These factors may be intrinsic (released by keratinocytes and fibroblasts, endocrine, inflammatory and neuronal cells) or extrinsic (UVR and drugs). ${ }^{3,6}$

Melanogenesis is a complex process with different stages. When disturbed, it may determine different types of pigmentation defects, which are classified as hypo or hyperpigmentation and which may occur with or without an altered number of melanocytes. ${ }^{1,2,7}$ There are several dermatoses associated with pigmentation defects which can be congenital or acquired, permanent or temporary, systemic or skin-restricted. ${ }^{7}$ Since these dermatoses have an important impact on patient quality of life and their treatment can be unsatisfactory, pharmaceutical and cosmetic industries have been continuously seeking new solutions. ${ }^{8,9}$ The understanding of the mechanisms of melanogenesis helps us to explain the pigmentation defects observed in genodermatoses and allows the development of potential therapeutic strategies. ${ }^{3,10}$ In this review, we describe the intrinsic and extrinsic factors that regulate human skin pigmentation, focusing on melanogenesis mechanisms and related genodermatoses.

\section{METHODS}

This review includes research articles which are indexed in PubMed (basic electronic bibliographic database), written in English, and available on the Internet. They can be found through the following search terms: Human melanogenesis; Melanocyte Biology and Pigmentation Skin; Pigmentation disorders. The abbreviations used in this article are listed in chart 1.

\section{MECHANISMS OF MELANOGENESIS}

\section{Stages of the melanogenesis process}

Melanocytes originate in neural crest melanoblasts that migrate to different destinations, including the basal layer of the epidermis and hair follicles, after closure of the neural tube. ${ }^{3,11,12}$ Their migra- tion, proliferation, and differentiation into melaninproducing cells depend on mediators produced by cells of the dorsal neural tube, ectoderm and keratinocytes, such as the family of glycoproteins WNT, endothelin 3 (EDN3), and stem cell factor (SCF), which binds the c-Kit receptor tyrosine kinase in melanocytes and melanoblasts. ${ }^{3,12}$ Bone morphogenic proteins antagonize these events, and their expression is reduced in melanocyte migration. Piebaldism, a genodermatosis with depigmented macules, is caused by mutations in the c-kit and SCF genes (Chart 2). ${ }^{3,10,12}$ Melanin synthesis occurs in melanosomes, lysosome-related organelles (LROs) whose defects are responsible for Chediak-Higashi Syndrome and Hermansky-Pudlak Syndrome, diseases with cutaneous hypopigmentation and systemic manifestations (Chart 2). ${ }^{6,10,11,13}$

The key proteins involved in skin pigmentation, such as the components of the fibrillar matrix that binds to melanin (glycoprotein Pmel17) and melanogenic enzymes, are located in melanosomes. In these organelles, the structural matrix is arranged, the tyrosinase enzyme is acquired, and melanin is synthesized along four maturation stages. ${ }^{2,3,6,13}$ The acquisition of melanogenic enzymes is regulated by a membraneassociated transporter protein (MATP), and mutations of the respective gene determine Oculocutaneous Albinism type 4. $^{3,6,10}$ When melanin synthesis is completed, melanosomes move bi-directionally from the perinuclear area towards melanocyte dendrites, in a movement controlled by microtubule proteins (kinesin, dynein). This transport ends with melanosomes binding actin filaments through a complex formed by myosin Va, Rab27a, and melanophilin $(\mathrm{mlph}){ }^{2}$ Mutations in the corresponding genes determine various forms of Griscelli Syndrome (Chart 2). ${ }^{6,10}$ An increase in intramelanosomal $\mathrm{pH}$ from 5 to 6.8, which depends on the proton pump p-protein in the melanosomal membrane, is needed for full maturation of melanosomes. ${ }^{14}$ On the one hand, the importance of this stage is supported by Oculocutaneous Albinism type 2, a disease which is caused by loss of functional p-protein and, on the other hand, it is supported by lower response to repigmentation treatment options, which is observed in Vitiligo patients who are also treated with proton pump inhibitors (Chart 2). ${ }^{6,12,14}$

In the epidermis, each melanocyte interacts through dendrites with 30 to 40 keratinocytes, allowing transfer of mature melanosomes to the cytoplasm of keratinocytes positioned strategically over nuclei. ${ }^{1,11}$ This transfer is not fully understood, and different mechanisms such as exocytosis, citophagocytosis, fusion of plasma membranes, and transfer by membrane vesicles are described. ${ }^{2}$ 
CharT 1: List of abbreviations

\begin{tabular}{|ll|}
\hline Term & Abbreviation \\
ACTH & Adrenocorticotropic hormone \\
$\alpha-$ MSH & Melanocyte-stimulating hormone \\
bFGF & Basic fibroblast growth factor \\
BMP & Bone morphogenic protein \\
cAMP & Cyclic adenosine monophosphate \\
cGMP & Cyclic guanosine monophosphate \\
c-kit & Mast cell growth factor \\
CREB & cAMP response element \\
ET & Endothelin \\
GM-CSF & Granulocyte-macrophage colony- \\
& sti mulating factor \\
IL & Interleukin \\
IP3/DAG & Inositol triphosphate/diacylglycerol \\
MAP & Mitogenic activated protein \\
MATP & Membrane-associated transporter \\
& protein \\
MC1-R & Melanocortin recetor type 1 \\
MITF & Microphthalmia-associated \\
NGF & transcription factor \\
NO & Neuronal growth factor \\
PG & Nitric oxide \\
PKA & Prostaglandin \\
PKC- $\beta$ & Protein kinase A \\
POMC & Protein kinase C- $\beta$ \\
ROS & Proopiomelanocortin \\
SCF & Reactive oxygen species \\
TNF- $\alpha$ & Stem cell factor \\
TRP & Tumor necrosis factor $\alpha$ \\
UVR & Tyrosinase-related protein \\
& Ultraviolet radiation \\
\hline
\end{tabular}

\section{Phenotypic diversity of pigmentation and types of melanin}

Phenotypic diversity of pigmentation is not due to a variation in melanocyte number, which is relatively constant in different ethnic groups, but to the size and number of melanosomes, the amount and type of melanin, and melanin transfer and distribution in keratinocytes. ${ }^{13,11}$ The melanosomes of dark-skinned individuals are larger, more numerous, and elongated, resulting in delayed degradation in keratinocytes and consequently in increased visible pigmentation. ${ }^{3,11,13}$ These differences in melanosomes are present at birth and are not determined by extrinsic factors such as UVR. ${ }^{3}$

There are two types of melanin: eumelanin brown-black or dark insoluble polymer -and pheomelanin - red-yellow soluble polymer formed by the conjugation of cysteine or glutathione (Figure 1). ${ }^{11,13,15}$ Eumelanin is the major type in individuals with dark skin and hair and is more efficient in photoprotection. Pheomelanin is predominantly found in individuals with red hair and skin phototypes I and II, in whom skin tumors are more common. ${ }^{5,11}$

\section{Enzymes of melanogenesis}

Tyrosinase is a glycoprotein located in the melanossomal membrane, with an internal, a transmembrane, and a cytoplasmic domain. It is a copperdependent enzyme that catalyzes the conversion of Ltyrosine into L-DOPA, the rate-limiting stage in melanin synthesis (Figure 1). ${ }^{2,14,15}$ Mutations that inactivate this enzyme are responsible for the most severe form of Albinism, that is, Oculocutaneous Albinism type 1 (Chart 2). ${ }^{6}$ The cytoplasmic domain participates in the transport of the enzyme from the nucleus to melanosomes. The internal domain contains the catalytic region (approximately 90\% of the protein) with histidine residues, where the copper ions bind. ${ }^{2}$ Mutations in the copper carrier (ATP7A) result in Menkes Disease (Chart 2) ${ }^{6}$ If copper is oxidized, the enzyme is inactivated and can be activated by electron donors such as L-DOPA, ascorbic acid, superoxide anion, and possibly nitric oxide (NO). ${ }^{14,15}$ Due to the fact that this enzyme can use superoxide anion as a substrate for melanogenesis, it may protect melanocytes from reactive oxygen species (ROS). ${ }^{11,16}$ The phosphorylation of two serine residues from the cytoplasmic domain by protein kinase C- $\beta$ (PKC- $\beta$ ) is also important for tyrosinase activation. ${ }^{17}$

Tyrosine hydroxylase isoform I (THI) is present in the melanosomal membrane adjacent to tyrosinase and catalyzes the conversion of L-tyrosine into LDOPA, promoting the activation of tyrosinase.

In cytosol, phenylalanine hydroxylase (PAH), cofactor 6BH4 (6-tetrahydrobiopterin)-dependent, catalyzes the conversion of L-phenylalanine to L-tyrosine, the tyrosinase substrate, thus also promoting its activation. ${ }^{14,15}$ Schallreuter et al., underlining the central role of tyrosinase, consider that these three enzymes are required for the beginning of melanogenesis. ${ }^{14}$

Two proteins similar to tyrosinase ( $40 \%$ homologous amino acids), tyrosinase-related protein-1 (TRP-1) and tyrosinase-related protein-2 (TRP-2), are also present in the membrane of melanosomes. Although its precise role is not yet clarified, it is possible that TRP- 1 has a role in the activation and stabilization of tyrosinase, melanosome synthesis, increased eumelanin/pheomelanin ratio and a role against oxidative stress due to its peroxidase effect (Figure 1). ${ }^{2,15}$ The results found by Jimbow et al. suggest that the premature death of melanocytes in Vitiligo is related to an increased sensitivity to oxidative stress caused by changes in TRP- $1 .{ }^{18}$ Mutations in TRP-1, present in Oculocutaneous Albinism type 3, result in skin and hair hypopigmentation (Chart 2). ${ }^{6}$ TRP-2 acts as a dopacrome tautomerase and, similarly to tyrosinase, requires a metal ion for its activity, zinc instead of copper (Figure 1)., ${ }^{2,14}$ Figure 1 shows the 
Chart 2: Genodermatoses with hypopigmentation or depigmentation

\begin{tabular}{|c|c|c|c|}
\hline Genodermatoses & Defect in melanogenesis & Affected gene & Heredity; clinical characteristics \\
\hline Piebaldism & $\begin{array}{l}\text { Melanoblast proliferation } \\
\text { skin macules }\end{array}$ & C-KIT, SCF & $\begin{array}{l}\text { Autossomic Dominant (AD); depigmented } \\
\text { and migration and white forelock }\end{array}$ \\
\hline $\begin{array}{l}\text { Waardenburg } \\
\text { Syndrome (WS) }\end{array}$ & $\begin{array}{l}\text { Melanoblast proliferation } \\
\text { and migration }\end{array}$ & $\begin{array}{l}\text { WS1 and WS3, PAX3 } \\
\text { WS2, MITF, SOX10 } \\
\text { WS4: SOX10, EDN3 }\end{array}$ & $\begin{array}{l}\text { Autossomic Dominant (AD); depigmented skin } \\
\text { macules and white forelock, heterochromia } \\
\text { of the iris, deafness }\end{array}$ \\
\hline Tietz Syndrome & $\begin{array}{l}\text { Melanoblast proliferation } \\
\text { and migration }\end{array}$ & MITF & $\begin{array}{l}\text { Autossomic Dominant (AD); hypopigmentation } \\
\text { and deafness }\end{array}$ \\
\hline $\begin{array}{l}\text { Oculocutaneous } \\
\text { Albinism (OCA) }\end{array}$ & Melanin synthesis & $\begin{array}{l}\text { OCA1: TR } \\
\text { OCA2: OCA2 (p gene) } \\
\text { OCA3: TRP1 } \\
\text { OCA4: MATP }\end{array}$ & $\begin{array}{l}\text { Autossomic Recessive (AR); pink skin, white } \\
\text { hair, blonde, brown, red pupils, reduced } \\
\text { visual acuity, nystagmus, } \\
\text { photophobia }\end{array}$ \\
\hline Menkes Syndrome & Melanin synthesis & ATP7A & $\begin{array}{l}\text { X-linked recessive; sparse scalp hair, spleen, } \\
\text { white or gray, neurological disorders }\end{array}$ \\
\hline $\begin{array}{l}\text { Chediak-Higashi } \\
\text { Syndrome }\end{array}$ & Melanosome synthesis & LYST & $\begin{array}{l}\text { Autossomic Recessive (AR); silvery sheen of } \\
\text { the skin and hair, hypo pigmentation of the } \\
\text { iris, neurological disorders, ocular albinism, } \\
\text { immunodeficiency, pancytopenia }\end{array}$ \\
\hline $\begin{array}{l}\text { Hermansky-Pudlak } \\
\text { Syndrome (HPS) }\end{array}$ & Melanosome synthesis & HPS & $\begin{array}{l}\text { Autossomic Recessive (AR) white patches on } \\
\text { the skin and ocular albi nism, bleeding } \\
\text { tendency }\end{array}$ \\
\hline $\begin{array}{l}\text { Griscelli } \\
\text { Syndrome (GS) }\end{array}$ & Melanosome transfer & $\begin{array}{l}\text { GS1: MYO5A } \\
\text { GS2, RAB27A } \\
\text { GS3: HPLM }\end{array}$ & $\begin{array}{l}\text { Autossomic Recessive (AR); skin and hair } \\
\text { hypopigmentation, ocular albinism, } \\
\text { neurological disorders }\end{array}$ \\
\hline
\end{tabular}

Adapted from DessiniotI C et al., 2009. ${ }^{10}$

LYST (gene of factor that regulates lysosome transport); OCA2 (gene of proton pump p-protein), TR (gene of tyrosinase).

synthesis of the two types of melanin and the functions of the major enzymes involved.

\section{Melanocortin 1 receptor (MC1-R)}

Melanocortin receptors belong to the family of G-protein receptors. MC1-R predominates in melanocytes and its agonists include melanocyte stimulating hormone ( $\alpha-\mathrm{MSH})$ and adrenocorticotropic hormone $(\mathrm{ACTH})$, both cleavage products of proopiomelanocortin (POMC). POMC is cleaved by carboxypeptidase- 1 in ACTH and $\beta$-lipotrophin and by carboxypeptidase- $2 \beta$ in endorphin and ACTH. ACTH is fragmented in ACTH 1-17 and $\alpha$-MSH. ACTH and $\alpha-$ MSH share the tetrapeptide His-Phe-Arg-Trp, which is essential for melanotropic activity. This peptide is the main intrinsic regulator of pigmentation, but its pitu- itary production is insufficient to stimulate melanogenesis; thus, keratinocytes and melanocytes are the main responsible for its production on the skin. ${ }^{1,5,11,13,15,16,19}$ Addison's Disease with high levels of ACTH, ACTH-producing tumors (Nelson Syndrome), and cases of prolonged administration of this hormone are associated with hyperpigmentation, particularly in sun-exposed areas. ${ }^{1,2,15}$

MC1-R genetic polymorphisms are responsible for ethnic differences of constitutive pigmentation and for different responses to UVR exposure. ${ }^{2,5,11,16}$ In individuals with red hair and light skin there is a high incidence of MC1-R mutations, which may be responsible for a decreased response to $\alpha-\mathrm{MSH}$, resulting in decreased eumelanogenesis and reduced pigmentation induced by UVR exposure. ${ }^{11}$ 


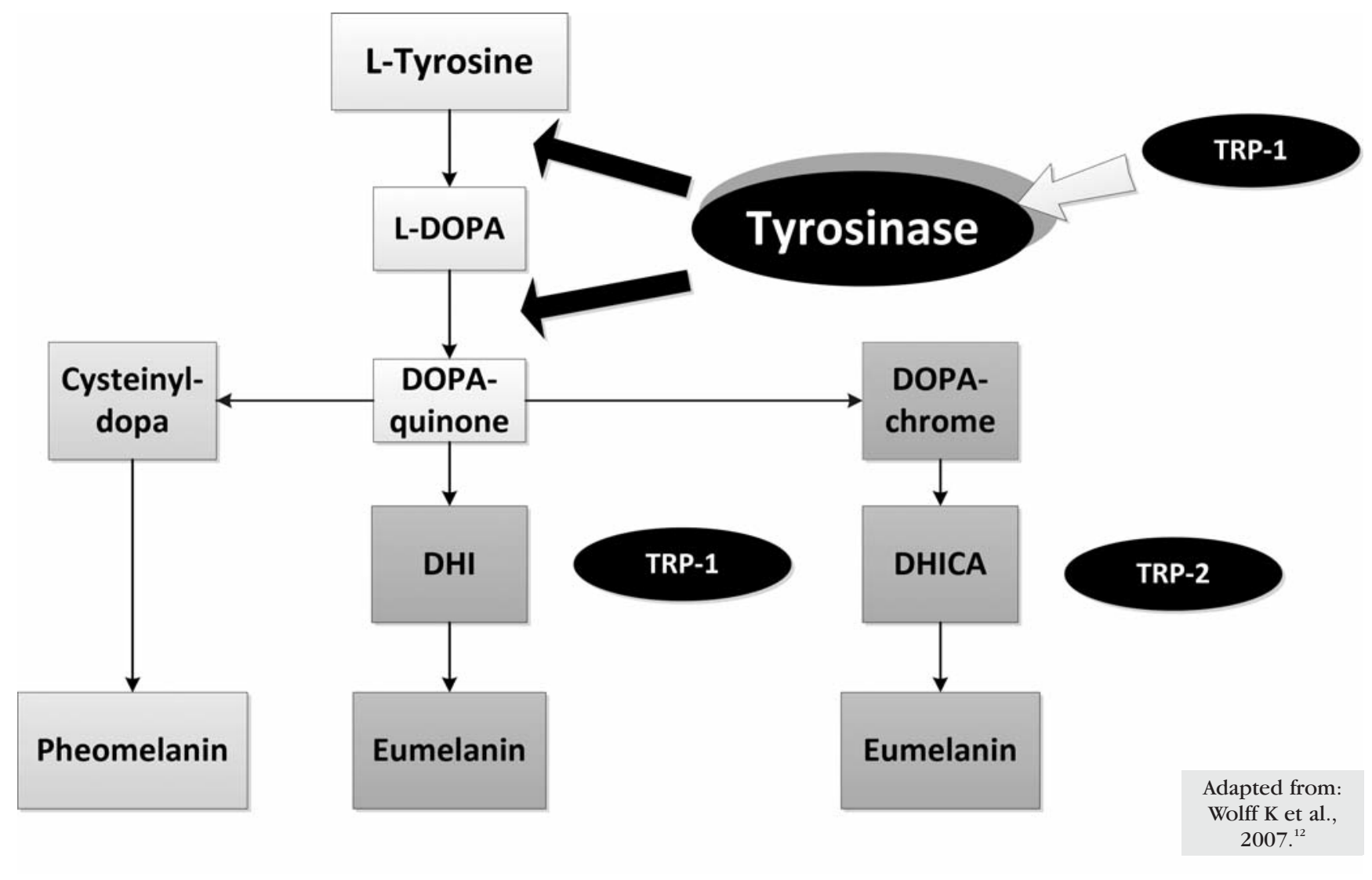

Figure 1: Synthesis of the two types of melanin and representation of the functions of the major enzymes involved

The Agouti signaling protein, although poorly documented, is the only known antagonist of MC1-R, competing with $\alpha$-MSH and, therefore, stimulating pheomelanogenesis. MC1-R activation by POMC peptides stimulates the accumulation of eumelanin instead of pheomelanin.

MC1-R agonists activate the adenylate cyclase enzyme, increasing intracellular cAMP and activating protein kinase A (PKA). PKA phosphorylates CREB (cAMP response element), which acts as a transcription factor in several genes, including the microphthalmia-associated transcription factor (MITF). MITF in its phosphorylated active form regulates the expression of melanogenic enzymes, promoting eumelanogenis. ${ }^{2,5,11,13,15}$ Its phosphorylation depends on kinases of mitogen-activated protein (MAP) whose activity is induced by the binding of keratinocyte-produced-SCF to the c-kit receptor tyrosine kinase. ${ }^{11,12}$ In addition to CREB, the expression of the MITF protein is regulated by other transcription factors and mediators produced by keratinocytes and fibroblasts. ${ }^{6,20}$ Moreover, the MITF protein regulates the expression of the Rab27a protein, which is important in melanosome transport, the melanosomal matrix protein Pmel17, and an anti-apoptotic protein (bcl-2) of melanocytes, which is often expressed in melanomas. ${ }^{2,10,12,20}$ MITF gene mutations are responsible for Waardenburg Syndrome type 2, with cutaneous and iris hypopigmentation, and Tietz Syndrome, with hypopigmentation and deafness (Chart 2). ${ }^{1,10,20}$

\section{Intrinsic regulation of skin pigmentation} Melanocytes produce POMC peptides, cytokines, NO, prostaglandins, and leukotrienes, which act via an autocrine or paracrine way on keratinocytes, and are involved in immune and inflammatory responses. Keratinocytes also produce several factors in response to UVR exposure, with paracrine action on melanocytes, which may stimulate or inhibit melanogenesis (Chart 3) ${ }^{2,6,11,12}$ Our group investigated the role of the recently described cutaneous endocannabinoid system in melanogenesis and demonstrated that UVR also activates endocannabinoid production by keratinocytes and that a paracrine cannabinoid receptor type 1-mediated endocannabinoid signaling negatively regulates melanin synthesis. ${ }^{21}$

Although POMC/MC1-R/CAMP is the main pathway, there are other melanocyte receptors associated with adenyl cyclase and cAMP production, such as muscarinic receptors and $\alpha$ and $\beta$ estrogen receptors. The increase in estrogen levels during pregnancy can 


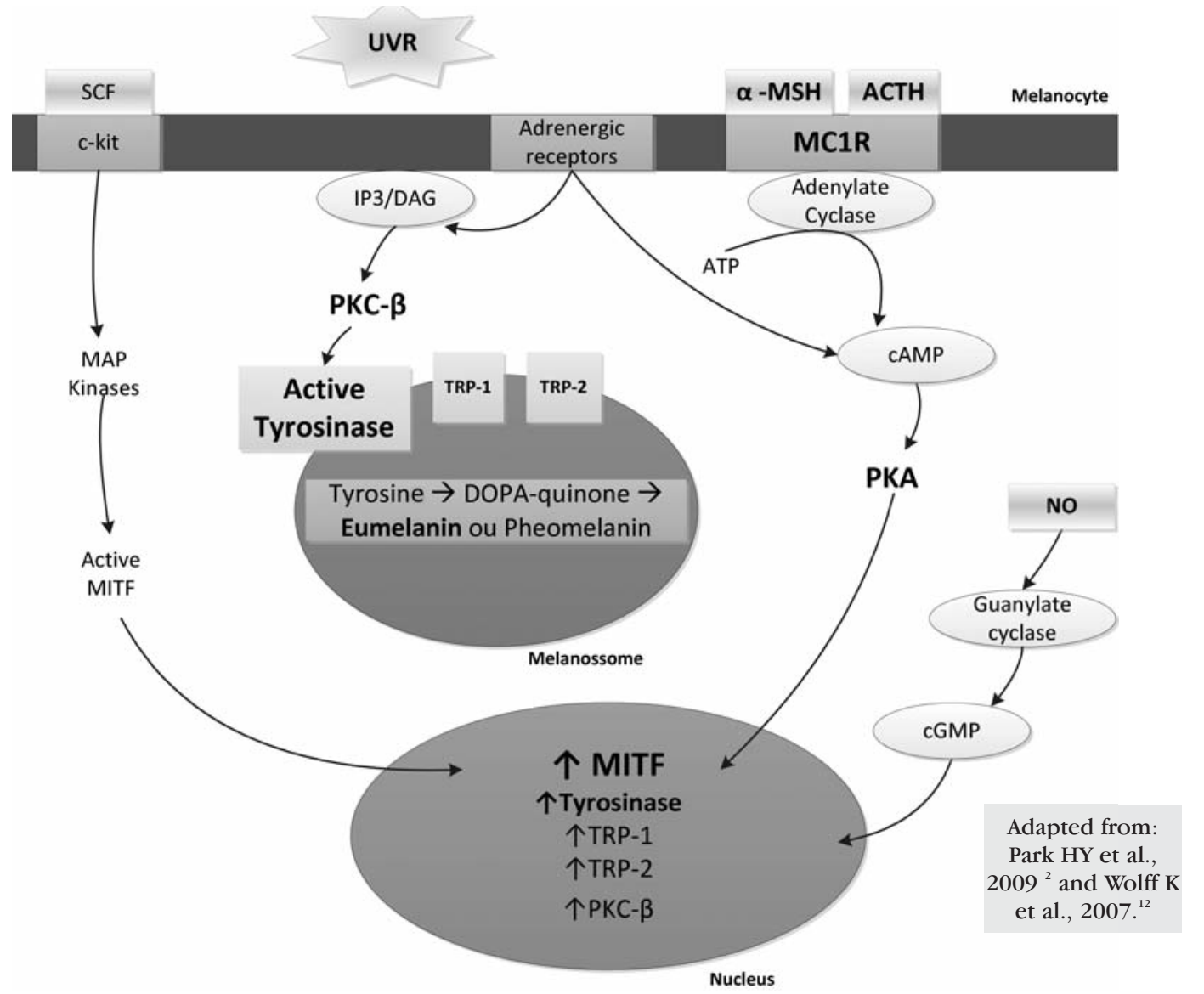

Figure 2: Melanocyte role and representation of the different signaling pathways regulating melanogenesis: activation factors, receptors, second messengers, and melanogenic enzymes cause hyperpigmentation (melasma, areolar hyperpigmentation and line nigricans). ${ }^{6}$ Catecholamines may be produced by keratinocytes from L-DOPA, the melanin precursor, and can bind to $\alpha 1$ and $\beta 2$ adrenergic receptors in melanocytes, stimulating melanogenesis via the cAMP pathway and PKC- $\beta .{ }^{15,22}$ This redundancy of cAMP production reveals the importance of this second messenger in melanogenesis. However, norepinephrine/ $\alpha 1$ adrenergic receptor, ACTH 1-17/MC1-R can also activate the inositol trisphosphate/diacylglycerol (IP3/DAG) pathway, which promotes the release of calcium in the cytoplasm of melanocytes. ${ }^{2,14,22}$ DAG is important for the activation of PKC- $\beta$, which phosphorylates tyrosinase, and can also be released from melanocytes through UVR action in the lipid membrane. ${ }^{3,14,17}$ Figure 2 illustrates some of the different pathways, receptors, second messengers, and melanogenic enzymes involved in melanogenesis.

\section{Extrinsic regulation of skin pigmentation by ultraviolet radiation (UVR)}

UVR is the most important extrinsic factor in the regulation of melanogenesis. It is the main stimulus for induced or acquired pigmentation, known as "tanning" ${ }_{1,2,6,11}$ There are two types of induced pig- mentation, which depends on genetic factors and is more evident in individuals with dark skin and hair. ${ }^{3,23}$ Immediate pigmentation, which appears 5-10 minutes after exposure to UVR, disappears minutes or days later, is largely due to UVA, and is not dependent on increased melanin synthesis, but on the oxidation of pre-existing melanin and redistribution of melanosomes to the epidermal upper layers. Delayed pigmentation, which occurs 3-4 days after exposure to UVR, disappears within weeks, is due to UVA and mainly UVB radiation, and results from an increased level of epidermal melanin, particularly eumelanin, providing photoprotection. ${ }^{3,12,13,16,23}$

On the one hand, UVR increases proliferation and/or recruitment of melanocytes, the number of dendrites, and the transfer of melanosomes to a supranuclear location on the keratinocytes for DNA photoprotection. On the other hand, the expression of POMC peptides, MC1-R, and melanogenic enzymes increases in keratinocytes and melanocytes respectively. ${ }^{11,13,16,23}$

DNA, the main cellular chromophore, directly absorbs UVR with the formation of thymine dimers and other pyrimidine derivatives, and defects in DNA repair increase the risk of skin cancer. ${ }^{1-3,5}$ The key observation that the UVR spectra for producing a delayed tan and for induction of thymine dimers fol- 
CHART 3: Effects of factors secreted by keratinocytes after exposure to UVR, with paracrine action

\begin{tabular}{|llllll|}
\hline & $\begin{array}{l}\text { Melanocyte } \\
\text { proliferation }\end{array}$ & Dendricity & $\begin{array}{l}\text { Melanin } \\
\text { synthesis }\end{array}$ & $\begin{array}{l}\text { Melanosome } \\
\text { transfer }\end{array}$ & $\begin{array}{l}\text { Survival / } \\
\text { Cytoprotection }\end{array}$ \\
ACTH & $\uparrow$ & $\uparrow$ & & $\uparrow$ \\
$\alpha-M S H$ & $\uparrow$ & $\uparrow$ & $\uparrow$ & $\uparrow$ & \\
bFGF & $\uparrow \uparrow$ & $\uparrow$ & $\uparrow$ & & \\
ET-1 & $\uparrow$ & $\uparrow$ & $\uparrow$ & & \\
GM-CSF & $\uparrow$ & & $\uparrow$ & $\uparrow$ \\
NO & & $\uparrow$ & $\uparrow$ & & \\
NGF & & $\uparrow$ & $\downarrow$ & & \\
PGE2/PGF2 $\alpha$ & & $\uparrow$ & $\downarrow$ & & \\
IL-1 & $\downarrow$ & & $\downarrow$ & \\
TNF- $\alpha$ & & & & & \\
BMP- 4 & & & & & \\
\hline
\end{tabular}

Adapted from Wolff $\mathrm{K}$ et al., 2007. ${ }^{12}$

ACTH (adrenocorticotropic hormone), $\alpha$-MSH (melanocyte-stimulating hormone), bFGF (basic fibroblast growth factor), BMP-4 (bone morphogenic protein-4), ET-1 (endothelin-1), GM-CSF (granulocyte-macrophage colony-stimulating factor), IL-1 (interleukin 1), NO (nitric oxide), NGF (nerve growth factor); PGE2/PGF2 $\alpha$ (prostaglandin E2 and F2 $\alpha$ ), TNF- $\alpha$ (tumor necrosis factor- $\alpha$ ).

lowing UVR were virtually identical and within the UVB range suggested for the first time a cause-effect relation between DNA damage and melanogenesis. ${ }^{24,25}$ In the last decade, it was recognized that the tumorsupressor protein $\mathrm{p} 53$ is a transcription factor that plays a pivotal role in the tanning response after UVBinduced DNA damage. ${ }^{26}$ Using an elegant mouse model in which UVR causes tanning, it was demonstrated that $\alpha$-MSH production is regulated in keratinocytes by $\mathrm{p} 53$ via a $\mathrm{p} 53$ consensus sequence in the POMC gene promoter. $^{27}$ Furthermore, Eller et al. demonstrated in vitro that small fragments of DNA induced pigmentation by increasing tyrosinase expression and activity and the levels of the tumor suppressor protein $\mathrm{p} 53 .{ }^{1,28}$ Cui et al. found that activation of p53 in keratinocytes increases the expression and release of POMC peptides. ${ }^{27}$ Even in the absence of keratinocytes, there is a strong melanogenic response to UVR mediated by $\mathrm{p} 53$ in human melanocytes and melanoma cells in vitro, which can be explained by the fact that $\mathrm{p} 53$ regulates the transcription of the hepatocyte nuclear factor $1 \alpha$ (HNF$1 \alpha)$, a tyrosinase transcription factor, in melanocytes. ${ }^{2,14,26}$

UVR also enhances reactive oxygen species (ROS) formation in keratinocytes and melanocytes, with consequent DNA damage. ${ }^{3,5}$

Regardless of the specific mechanisms, acquired pigmentation is part of the skin adaptive response, mediated by $\mathrm{p} 53$, to DNA damage caused by exposure to UVR and will provide skin protection in future exposures. ${ }^{2,26}$

It has been shown that plasma membrane lipids are also affected by UVR to release membrane-associated diacylglycerol (DAG), which activates PKC- $\beta$. In turn, PKC- $\beta$ activates tyrosinase, resulting in stimulation of melanogenesis. ${ }^{14}$

An elderly individual, depending on constitutive pigmentation and cumulative UVR dose, may have hyperpigmented lesions (solar lentigines) that indicate photoaging. This can be explained by the fact that aged melanocytes possess an enhanced functional activity after years of cumulative UVR exposure. However, with aging, there is also a decrease in the number of functional melanocytes. ${ }^{3}$ Eumelanin acts as a natural sunscreen against photoaging and photocarcinogenesis, in part by reducing ROS and increasing repair of DNA damage. ${ }^{5,13,15}$

\section{CONCLUSION}

Melanocytes are responsible for the cutaneous synthesis and distribution of melanin, an essential pigment for photoprotection. This process, which is called melanogenesis, involves different stages, from melanocyte embryogenesis to melanosome transfer to neighboring keratinocytes. The importance of each of these stages and their mechanisms is evident in clinical genetic defects (genodermatoses with depigmentation or hypopigmentation). The identification of these defects has contributed to a better understanding of 
the melanocyte biology and melanogenesis regulation. The study of melanogenesis has revealed different kinds of interaction between melanocytes and other cells (including keratinocytes) and systems (CNS, immune, inflammatory, endocrine, and endocannabinoid), and this raises the role of skin as a neuroendocrine organ.

Many factors are known as regulators of melanin synthesis, and we point out UVR as an important extrinsic factor and $\alpha-\mathrm{MSH}$ as an important intrinsic factor. Alpha-MSH exerts its effect mainly as an agonist of MC1-R, whose genetic polymorphisms partially explain phenotypic diversity and different responses to UVR. In induced pigmentation, UVR has a direct

\section{REFERENCES}

1. Lin JY, Fisher DE. Melanocyte biology and skin pigmentation. Nature. 2007;445:843-50.

2. Park HY, Kosmadaki M, Yaar M, Gilchrest BA. Cellular mechanisms regulating human melanogenesis. Cell Mol Life Sci. 2009;66:1493-506.

3. Costin GE, Hearing VJ. Human skin pigmentation: melanocytes modulate skin color in response to stress. FASEB J. 2007;21:976-94.

4. Plensdorf S, Martinez J. Common pigmentation disorders. Am Fam Physician. 2009;79:109-16.

5. Rouzaud F, Kadekaro AL, Abdel-Malek ZA, Hearing VJ. MC1R and the response of melanocytes to ultraviolet radiation. Mutat Res. 2005;571:133-52.

6. Yamaguchi Y, Hearing VJ. Physiological factors that regulate skin pigmentation. Biofactors. 2009;35:193-9

7. Fistarol SK, Itin PH. Disorders of pigmentation. J DtschDermatolGes 2010; 8:187-201.

8. Grimes PE. Management of hyperpigmentation in darker racial ethnic groups. SeminCutan Med Surg. 2009;28:77-85

9. Ebanks JP, Wickett RR;Boissy RE. Mechanisms regulating skin pigmentation: the rise and fall of complexion coloration. Int J Mol Sci. 2009;10:4066-87.

10. Dessiniotl C, Stratigos AJ, Rigopoulos D; Katsambas AD. A review of genetic disorders of hypopigmentation: lessons learned from the biology of melanocytes. ExpDermatol. 2009;18:741-9.

11. Tsatmali M, Ancans J,Thody AJ. Melanocyte function and its control by melanocortin peptides. J HistochemCytochem. 2002;50:125-33.

12. Park HY, Pongpudpunth M, Lee J, Yaar M. Biology of Melanocytes. In: Wolff K, Goldsmith LA, Katz SI, Gilchrest BA, Paller AS, Leffel DJ, editors. Fitzpatrick's Dermatology in General Medicine. McGraw Hill: New York; 2007. p.591-608.

13. Schiaffino MV. Signaling pathways in melanosome biogenesis and pathology. Int $J$ Biochem Cell Biol 2010; 42:1094-104.

14. Schallreuter KU, Kothari S, Chavan B, Spencer JD. Regulation of melanogenesis-controversies and new concepts. ExpDermatol. 2008;17:395-404.

15. Slominski A, Tobin DJ, Shibahara S, Wortsman J. Melanin pigmentation in mammalian skin and its hormonal regulation. PhysiolRev. 2004;84:1155-228.

16. Thody AJ, Graham A. Does alpha-MSH have a role in regulating skin pigmentation in humans? Pigment Cell Res 1998; 11:265-74.

17. Park HY, Perez JM, Laursen R, Hara M, Gilchrest BA. Protein kinase C-beta activates tyrosinase by phosphorylating serine residues in its cytoplasmic domain. J Biol Chem. 1999;274:16470-8.

18. Jimbow K, Chen H, Park JS; Thomas PD. Increased sensitivity of melanocytes to oxidative stress and abnormal expression of tyrosinase-related protein in vitiligo. $\mathrm{Br}$ J Dermatol. 2001;144:55-65.

19. Gantz I; Fong TM. The melanocortin system. Am J PhysiolEndocrinolMetab. 2003;284:E468-74 effect mediated by $\mathrm{p} 53$ tumor suppressor protein and an indirect effect mediated by keratinocyte production of intrinsic factors, promoting eumelanin synthesis. UVR is responsible for "tanning", but is also associated with aging, skin with hyperpigmented lesions, and development of skin tumors.

Investigating the mechanisms of melanogenesis is important for understanding pigmentation defects and for the consequent development of potential therapeutic agents. It also allows for the development of photoprotective measures, which reduce photoaging and photocarcinogenesis. This is an important area of research where there is still much to be clarified and learned.
20. Steingrimsson E, Copeland NG, Jenkins NA. Melanocytes and the microphthalmia transcription factor network. Annu Rev Genet. 2004;38:365-411.

21. Magina S, Esteves-Pinto C, Moura E, Serrão MP, Moura D, Petrosino S, et al. Inhibition of basal and ultraviolet B-induced melanogenesis by cannabinoid $\mathrm{CB}(1)$ receptors: a keratinocyte-dependent effect. Arch Dermatol Res. 2011;303:201-10.

22. Grando SA, Pittelkow MR, Schallreuter KU. Adrenergic and cholinergic control in the biology of epidermis: physiological and clinical significance. J Invest Dermatol. 2006;126:1948-65.

23. Tadokoro T, Yamaguchi Y, Batzer J, Coelho SG, Zmudzka BZ, Miller SA, et al Mechanisms of skin tanning in different racial/ethnic groups in response to ultraviolet radiation. J Invest Dermatol. 2005;124:1326-32.

24. Parrish JA, Jaenicke KF, Anderson RR. Erythema and melanogenesis action spectra of normal human skin. PhotochemPhotobiol. 1982;36:187-91.

25. Freeman SE, Hacham H, Gange RW, Maytum DJ, Sutherland JC, Sutherland BM. Wavelength dependence of pyrimidine dimer formation in DNA of human skin irradiated in situ with ultraviolet light. ProcNatIAcadSci U S A. 1989;:5605-9.

26. Khlgatian MK, Hadshiew IM, Asawanonda P, Yaar M, Eller MS, Fujita M, et al. Tyrosinase gene expression is regulated by $\mathrm{p} 53$. J Invest Dermatol.2002;118:126-32.

27. Cui R, Widlund HR, Feige E, Lin JY, Wilensky DL, Igras VE, et al. Central role of p53 in the suntan response and pathologic hyperpigmentation. Cell. 2007;128:853-64.

28. Eller MS, Ostrom K, Gilchrest BA. DNA damage enhances melanogenesis. ProcNatlAcadSci U S A. 1996;93:1087-92.

\author{
MAILING ADDRESS: \\ Inês Ferreira dos Santos Videira \\ Instituto de Farmacologia e Terapêutica da \\ Faculdade de Medicina da Universidade do Porto \\ Alameda Prof. Hernâni Monteiro, \\ 4200-319 Porto \\ E-mail address: ines_videira5@botmail.com
}

How to cite this article: Videria IFS, Moura DFL, Magina S. Mechanisms regulating melanogenesis. An Bras Dermatol. 2013;88(1)76-83. 